\title{
THE RELATIONSHIP BETWEEN STUDENTS' ENGLISH INTEREST AND VOCABULARY MASTERY TOWARD WRITING ABILITY
}

\author{
Iful Rahmawati Mega, M.Pd \\ iful.rahmawati@stkipmbb.ac.id \\ STKIP Muhammadiyah Bangka Belitung
}

\begin{abstract}
Penelitian ini merupakan penelitian kuantitatif dengan jenis korelasi ganda. Penelitian ini dilaksanakan bertujuan untuk mengetahui seberapa jauh hubungan antara penguasaan kosakata Bahasa Inggris, dan minat Bahasa Inggris terhadap kemampuan menulis Bahasa Inggris mahasiswa Program TOEFL dari Mahasiswa PGSD STKIP Muhammadiyah Bangka Belitung, baik secara parsial dan kesinambungan. Dalam penelitian ini menggunakan dua jenis tes sebagai teknik pengumpulan data yaitu tes pilihan ganda untuk mengambil data vocabulary, tes essay untuk mengambil data kemampuan menulis, serta menggunakan angket untuk mengumpulkan data minat Bahasa Inggris mahasiswa. Populasi dari penelitian ini adalah seluruh mahasiswa yang mengikuti Program Kelas TOEFL, dengan diambil 30 mahasiswa secara random sebagai sampel penelitian. Teknik pengolahan data dari penelitian ini menggunakan analisis single dan multiple korelasi dan regresi. Hasi akhir dari penelitian ini menunjukkan adanya hubungan positif antara penguasaan kosakata Bahasa Inggris, dan minat Bahasa Inggris terhadap Kemampuan Menulis Bahasa Inggris mahasiswa Program TOEFL dari Mahasiswa PGSD STKIP Muhammadiyah Bangka Belitung, baik secara parsial dan kesinambungan. Hubungan positif ini menunjukkan bahwa penguasaan kosakata Bahasa Inggris dan minat Bahasa Inggris cenderung naik dan turun bersamaan dengan kemampuan menulis Bahasa Inggris.
\end{abstract}

Keywords: Penguasaan Kosakata, Minat Bahasa Inggris, Kemampuan Menulis 


\section{INTRODUCTION}

Writing is an important skill in everyday life. It is needed when we are continuing our study to the higher level or when we are graduated from school and apply for a job. An application letter for the job plays an important role to consider. The diction one uses and the ability to convey message hold its own consideration. Although one is the smartest person in reading, without ability to write, he may be the second best person compared with the one that has good writing ability. It is also needed in the work to write reports, researches, and many other practical tasks.

Brown (2004: 218) states that today the ability to write has become an indispensable skill in our global literate community. In the same page, Brown also adds that in the field of second language teaching, only a half-century ago experts were saying that writing was primarily a convention for recording speech and for reinforcing grammatical and lexical features of language. From Brown's statements, it can be said that writing skill is a unique skill that has its own features and conventions to convey the meaning.

Compared with the three other language skills (listening, speaking, and reading), writing is considered the most difficult skill for some students. According to Bayle cited in Foo, et al (2012: 6), writing for Foreign Language students is considered to be the most complex and difficult to master and as rule, it is more complex than writing one's native language. Some problem that people faced in writing is about the vocabulary and tenses. In line with Cahyani and Hodijah (2007: 10) -keterampilan menulis merupakan keterampilan yang paling rumit karena menulis bukanlah sekadar menyalin kata-kata dan kalimat-kalimat, melainkan juga mengembangkan dan mengungkapkan pikiran-pikiran dalam suatu tulisan yang teratur", means that writing is the most complex skill because writing is not only copying words or sentences, but also developing and expressing ideas in proper writing. The students got difficulty in vocabulary especially on how to identify meaning, how to use the vocabulary based on the context, how to distinguish the right tenses in constructing sentences and how to arrange sentences into a good paragraph.

To create a good writing, students have to be more careful in many aspects, such as: careful construction, precise and varied vocabulary, correct spelling and punctuation, correct expression, acceptable grammar, and good paragraph development. According to Tarigan (2008: 22-23) "belajar menulis adalah belajar berpikir mendalam (berpikir kritis) dengan cara penemuan/pengalaman, penyusunan urutan pengalaman, dan ketepatan pemilihan 
kata", it means that, learning writing is learning to think critically with identifying experiences, arranging experiences, and the accuracy of selecting vocabulary. As stated this, vocabulary is one of the important aspect that influence writing. What a student needs to have the first time when he wants to write is vocabulary. Limited vocabulary will block them to convey the meaning. Lack of vocabulary also makes students confused and sometimes makes them misinterpret the meaning. Cameron in Widyastuti (2012: 2) believes that vocabulary acquisition and learning is essential for development in both oral and written language. Vocabulary is one of the most obvious components of language and one of the first things applied linguists turned their attention to (Jack Richard, 2001: 4). It implies that learning language cannot be separated from learning vocabulary.

Because learning language cannot be separated from learning vocabulary, vocabulary is the key of the successful people learn the language. Without a sufficient vocabulary, language learning process will be faced difficulty. It will make students unable to use the structure and functions they have learned for communication. Vocabulary mastery holds great contribution in communication. The most important thing in communication is that the meaning of the message can be conveyed clearly. If the meaning of the message cannot be understood, it can be said that there is no communication. The great role of vocabulary mastery in communication is depicted by Wilkins in Thornburry (2002:13) believes that without grammar very little can be conveyed, without vocabulary nothing can be conveyed. It will be clear, then, that vocabulary mastery is a crucial aspect to deliver ideas or convey messages in writing.

Another factor that influence writing ability is from the individual aspect, it is students' psychology. In doing something, a person will be satisfied if it is from the awareness of himself or herself than it is a force from the others, because the self-awareness is one of internal factors which can influence one's success. The factor which is meant is interest of learning. In this case is interest of English learning. When students have selfawareneess in English learning, they will be happy and interested to learn English subject, if they are happy and interested in it, they will study happily and always try to arrange good writing. From this review of the explanation above, it is expected that all of these aspects are influenced each other. The good writing ability is determined by vocabulary aspect and also students' English interest. 


\section{THEORETICAL REVIEW}

Hedge (1998: 5) stresses that compared with speech, effective writing requires a number of things: a high degree of organization in the development of ideas and information; a high degree of accuracy so that there is no ambiguity of meaning; the use of complex grammatical devices for focus and emphasis; and a careful choice of vocabulary, grammatical patterns, and sentence structures to create a style which is appropriate to the subject matter and the eventual readers. In addition, Nunan (1998: 6) says that writing involves mastering of the mechanics of letter formation and obeying convention of spelling and punctuation; using grammatical system to convey one's intended meaning; organizing content at the level of the paragraph and the complete text to reflect given/new information. In line with Harris (1993: 11) believes that some of the decisions that have to be made in the course of writing are concerned with the interrelationships between ideas or propositions; some are concerned with revealing as precisely as possible the nature of certain experiences - giving them, in fact, a shape; others are to do with the selecting and ordering of ideas, information, or experiences. From explanation above it can be concluded that writing involves a high organization in developing ideas and information, no ambiguity of meaning, use complex grammar, and choice the proper vocabulary.

In writing, there are some micro-skills and macro-skills that should be mastered by the students. Brown (2004: 221) states that the micro-skills and macro-skills of writing are as follows:

Micro-skills:

1. Produce graphemes and orthographic patterns of English

2. Produce writing at an efficient rate of speed to suit the purpose

3. Produce an acceptable core of words and use appropriate word order patterns

4. Use acceptable grammatical systems (e.g., tense, agreement, pluralization), patterns, and rules

5. Express a particular meaning in different grammatical forms

6. Use cohesive devices in written discourse and for Macro-skills:

7. Use the rhetorical forms and conventions of written discourse

8. Appropriately accomplish the communicative functions of written texts according to form and purpose

9. Convey links and connections between events, and communication such relations as 
main idea, supporting idea, new information, given information, generalization, and exemplification

10. Distinguish between literal and implied meanings when writing

11. Correctly convey culturally specific references in the context of the written text

12. Develop and use a battery of writing strategies, such as accurately assessing the audience's interpretation, using prewriting devices, writing with fluency in the first drafts, using paraphrases and synonyms, soliciting peer and instructor feedback, and using feedback for revising and editing.

As from explanation above, writing is about macro and micro skill that process of gathering and ordering ideas or information, forming into visible letter in a conventional manner includes grammar, vocabulary, organization, and mechanics as a means for communication.

To arrange a good writing it needs some process, Linse (2006: 105) states that the process of writing is often described as consisting of five activities; namely: prewriting, writing, revising, editing, and publishing.

1. Prewriting

In this prewriting step, the writers must know the purpose in their writing. Firstly, they have to select the subject that becomes a topic; it is to develop their ideas to give their first description of what to write. And then, they write the title. Title has to attract readers' attention.

2. Writing

Writing is a procedure for whether the ideas which have been discovered during planning can be shaped into sucessful writing. The ideas can be rearranged, added to, and edited.

3. Revising

The next step in writing is revising. Revising is the process of seeing again, or discovering a new division for the writing the students produce during prewriting and writing. Revising occurs when the writer looks for feedback from a teacher or other students. Revising should be focus on content and not grammatical or spelling errors.

4. Editing

Editing is used to correct error in grammar, sentence structure, spelling, and punctuation. Sometime the writers have a hard time accepting that editing is necessary.

5. Publishing

Publishing refers to put the writing in a final finishing format where it can be shared with 
other. Publishing can be a great motivator for the writer.

Another supported idea that desribe writing process is defined by Oshima and Hogue (2006: 265) states that writing as a process of creating, organizing, writing, and polishing. First, the writers creates their ides, and then organizes it, then it is written into rough draft, and the last polishes tha rough draft by editing and making revisions. So, from the explanation above, writing is needed the proper processes to develop the good writing.

To develop successful writing, there are some criteria, these are listed below as Nunan (1991: 3) stated:

1. Mastering the mechanics of letter formation;

2. Obeying conventions of spelling and punctuation;

3. Using grammatical system to convey one's intended meaning

4. Organizing content at the level of the paragraph and the complete text to reflect given new information;

5. Selecting an appropriate style for one's audience

On the other hand, Peha (2002: 3) states in order to create good writing there are some criteria, as follows:

1. Interesting and important ideas

2. Organization that is logical and effective

3. Voice that is individual and appropriate

4. Word choice that is specific and memorable

5. Sentence fluency that is smooth and expressive

6. Conventions which are correct and communicative

Also, the writer must to pay attention to the cohesion and coherence of the paragraph to create a good writing, there are:

1. Cohesion

Webster (2006: 348) cohesion is the act or state of sticking together tightly. Similar with Webster, Yule (2006: 125) defines that cohesion as the ties and connections that exist within texts. To achieve good cohesion, the link of one sentenceto the next, consider the following techniques:

a) Repetition

In the second sentence (the second of any two sentences), repeat a word from the previous sentence.

b) Synonym 
Use the =elegant variation', means use the synonym of the word that you wish to repeat.

c) Antonym

One of the idea to create sentence cohesion is using -oppositell word, since antonyms actually share more elements of menaing than you might imagine.

d) Pro-forms

Use a pronoun, pro-verb, or another pro-form to make explicit reference back to a form mentioned earlier.

e) Collocation

Use a commonly paired or expected or highly probable word to connect one sentence to another.

f) Enumeration

Use overt markers of sequence to highlight the connection between ideas. This system has many advantages: (a) it can link ideas that are otherwise completely unconnected, (b) it looks formal and distinctive, and (c) it promotes a second method of sentence cohesion.

g) Parallelism

Repeat a sentence structure. This technique is the oldest, most overlooked, but probably the most elegant method of creating cohesion.

h) Transitions

Use a conjunction or conjunctive adverb to link sentences with particular logical relationships.

2. Coherence

Coherence is product of many different factors, which combine to make every paragraph, every sentence, and every phrase contribute to the meaning of the whole piece. There must be some other factor that leads us to distinguish connected texts that make sense from those that do not. This factor is usually described as _coherence'. The key concept of coherence (_everything fitting together well ${ }^{\circ}$ ) is not something that exists in words or structures, but something that exists in people. Like stated in Yule (2006: 126) that is people who _make sense' of what they read and hear.

After define some criteria above, there are five aspects of writing from Hughes (1996: 91) as follows:

1. Grammar, that is an element of writing, that is an element of writing which deals with a 
set of rules to construct sentences that make sense and acceptable in English;

2. Vocabulary, it deals with a list of words and their meanings;

3. Mechanics, that is convention in writing, which is related to punctuation, spelling, and capitalization;

4. Fluency, which refers to the ease and the style of the composition; and

5. Form or organization that is the logical sequence and cohesion or the flow of the ideas being put into written language to make unified contribution to the whole paragraph. It is commonly called as generic structure.

From some criteria above, it can be stated that good writing is define about grammar, vocabulary, mechanics, fluency, and organization.

To support another review of writing ability, there are three kinds of writing as defined by Brown (2004: 219) as follows:

1. Academic writing

It is related to academic purposes; like papers, reports, essays, academic journal, academic article, theses, and dissertations.

2. Job-related wiriting

It is focused on messages, letters, emails, memos, labels, signs, advertisement, announcement, etc.

\section{Personal Writing}

It includes personal letters, greeting cards, invitations, shopping list, etc.

On the other hand, it is supported by Buscemi (1999: 78-79) says that there are four kinds of writing, those are description, narration, explanation, and persuasion. It is described as follows:

1. Description

It is used to describe a certain object, when the writer wants to give the detail information.

2. Narration

This writing is used to narrate some series of events as they occur in time and explain each event or part of an event. Narration writing can be divided into two types, fiction and non-fiction fiction is about born from the author's immagination, as it is entertained the reader; while non-fiction recounts events that actually occured. It is used by scientists to inform and to explain natural processes or events.

3. Explanation 
It is also called exposition. It is used to expose new ideas for the readers. It is the most common method for developing paragraph.

\section{Persuasion}

This kind is the attempt to convince readers that the writer's position on issue is valid. The main purpose is persuading the readers with the writer's idea.

So, there are different kinds in doing writing. It is based on the purpose. In this research, it is doing writing for the academic purpose, so it is focused on describing something in detail.

Beside that, in order to deliver the expression of the ideas, there are six general types of purpose. Each type of the purposes focuses on one of the parts of the communication model.

1. Writer: Expressive purposes

This type of writing does not take the reader into consideration; instead it focuses on the wirter's feeling, experience, and needs. Expresisve writing may take the form poetry, journals, letters, and especially, free writing.

2. Reader: Conative purposes

Conative writing quests to affect the reader. Conative writing may take about any form so long as its intention to persuade the reader or affect the reader emotionally.

3. Context: Informative purposes

Informative writing refers to something external to the writing itself with the purpose of informing the reader.

4. Message: Poetic purposes

Poetic (or literary or stylistic) purposes focus on the message itself - on its language, on the way the elements of language are used, on structure and pattern both on the level of phrase and of the overall composition.

5. Contact: Phatic purposes

Phatic language (and nonverbal communication) establishes and maintains contacts between speakers or between writer and reader. Phatic purposes are not significant in most writing. The use of greetings and closings in letters is one example of phatic purposes in writing

6. Code: Metalinguistic purposes

Comments on a piece of writing are metalinguistic. If a student attaches a note to an essay to explain why the essay is late, the note is metalinguistic in relation to the essay. An author's preface to a book is another example of metalinguistic purposes in writing. 
After defining some review about writing above, it can be concluded that writing is very important in expressing someone's ideas, it is also supported by selecting vocabulary properly. Coady and Huckin (1998: 5) state that vocabulary is central to language and critical importance to the typical language learner. Linse (2006: 121) says vocabulary is the collection of words that an individual knows. Furthermore, Read (2000: 16) says that vocabulary knowledge involves knowing the meanings of words and therefore the purpose of a vocabulary test is to find out whether the learners can match each word with a synonym, a dictionary-type definition or an equivalent word in their own language. It is explained that vocabulary is a central language that includes collection of words involving the meaning of words.

Vocabulary may also be defined as knowing a word. Richards in Read (2000: 25) states that the other seven assumptions cover various aspects of what is meant by knowing a word:

a. Knowing a word means knowing the degree of probability of encountering that word in speech or print. For many words we also know the sort of words most likely to be found associated with the word.

b. Knowing a word implies knowing the limitations on the use of the word according to variations of function and situation.

c. Knowing a word means knowing the syntactic behavior associated with the word

d. Knowing a word entails knowledge of underlying form of a word and the derivations that can be made from it.

e. Knowing a word entails knowledge of the network of associations between that word and the other words in language

f. Knowing a word means knowing the semantic value of a word

g. Knowing a word means knowing many of the different meanings associated with a word

Another description about vocabulary beside the seven assumptions is that vocabulary is one of the language elements which are very important in learning a language. Cameron (2001: 137) is of the opinion that vocabulary knowledge is extremely important: (a) when a written word is being _sounded out ${ }^{\star}$ or built up from its component letter or morpheme sounds, knowing the word already will speed up recognition, and (b) when sentence is being read, known words will be easier to hold in short-term memory as meaning is built up. In addition, Dellar and Hocking in Thornburry (2002:13) say:

"if you spend most of your time studying grammar, your English will not improve very much. 
You will see the most improvement if you learn more words and expressions. You can say very little with grammar, but you can say almost anything with words."

This statement above, do not to underestimate grammar; however, it shows the importance of vocabulary mastery in English Learning. Also according to Raimes in Nation (2008: 84) also stresses the need for an adequate vocabulary if learners are going to generate, develop, and present ideas in their writing. Without an adequate vocabulary, the idea may be not presented clearly. Furthermore, Nation (2008: 83) states:

-With writing however, learners need to extend their productive vocabulary to include the specialized vocabulary of their areas of study and interest. In academic settings, writing is most often used as the form of assessment and learners need to be able to show their knowledge of the field through the use of the specialized vocabulary.\|

This explanation is to strengthen that vocabulary mastery is important in language communication and important in developing of one's ideas. To build the paragraph in writing, it needs one's vocabulary mastery. Vocabulary also has components, since vocabulary is related to a word or word knowledge, the components of word knowledge are also the components of vocabulary.

As stated Nation in Read (2000: 26) that components of word knowledge are:

1. Form

In this components, are related to spoken form and written form. How the words pronounced, what the word sound likes, how the words written and spelled.

2. Position

It is about grammatical patterns and collocation. In what patterns the words occured, in what patterns that words must be used, what types of words can be expected before and after the words, and what types of words must be used.

3. Function

It dealings with the frequency and appropriateness. How the words is common, how often the words are used, where this word is expected meet, and where the words can be used.

4. Meaning

It is about the concepts and associations. The meaning of the words and the express meaning of the words.

Furthermore, stated in Penny Ur (1998: 60-62) the elements that needs to be taught in teaching vocabulary, they are: 
1. Form: Pronunciation and Spelling

2. Grammar

3. Collocation

4. Aspect of meaning

5. Word formation

From the explanation above, it can be concluded that vocabulary mastery means complete knowledge or great skill of a list of English words that includes the meaning of words, spelling, pronunciation, and the use of words in right context.

Beside vocabulary, another factors that influence good ability in writing is interest. According to Hazin (2004: 365) interest means attention, pleasure, and tendency. On the other hand, interest means tendency and higher enthusiasm or pretension about something (Burhanudin dan Esa, 2009: 24). Shaleh and Wahab (2011: 263) defines interest as a tendency to give attention and action to someone, activity, or situation which are an object of its interest happily.

From the explanation above, interest is tendency of mood's someone to do something without forcing. Someone will be known his or her interest if there is tendency to be interested to an object whether he or she is happy or unhappy, so it results a respond to something which he or she likes.

To reach the success in learning, student need to know learning interest. If his or her interest has not developed yet, it can be done by some alternative ways to develop it. Interest is constant tendency to pay attention and do something. Activity which is interested by someone will be paid attention continually and happily. So, interest is different from attention, because attention is temporary (it is not for a long time) and it is not certain followed by pleasure, while interest is always followed by pleasure and there is satisfying. Based on essence of interest above, it can be concluded that basic matters in definition of interest such as:

1. There is pleasure feeling from self which gives attention to the certain object.

2. There is like to the certain object.

3. There is activity or object which is chosen.

4. There is tendency to try more active.

5. The object or activity is viewed valuable in life.

6. It tends to guide or influence to behavior of individual.

Interest has an important role and it is an important factor in learning process, so it 
will influence their writing. Interest is as impetus of someone to do something which he or she faces so it also determines the result of activity of someone. Interest cannot be separated from fulfillment which emerges satisfied of himself. It also has indicators, there are pleasure, attention, attitude, fulfillment.

\section{Pleasure}

A student has pleasure of English, so she or he will always learn English happily. He or she is not forced. By pleasure to English, the English interests will arise, so the result of English learning will be better. On the contrary, without pleasure to English, the English interests will not arise, so the result of English learning will be worse.

2. Attention

Attention is the concentration or activity of our souls towards observation, understanding, and so on by ignoring the others. Student who is interested in English will pay attention more to English. He/she will focuse in English learning.

3. Attitude

Someone who is interested in an object will utter the positive attitude to the object. Example, student who is interested in English will utter the positive attitude in his or her learning; he will be enthusiastic, active, and creative.

\section{Fulfillment}

Interest will be appeared if someone feel fulfillment by following the activity. She or he feels that the activity is benefit.

Beside indicators, interest also has some factors that influence, they are stated in Nurhidayati (2006: 14) said there are many factors that influence students' interest such as: motivation, learning, learning materials and teachers, families, their friends, environments, aspires, talents, hobbies, mass media, and facilities.

In a certain activity, it has a purpose to be reached. By knowing the purpose of activity, it will raise the interest. Children will have interest to study, if the learning situation is interesting, such as it is not noisy, the place is tidy, the tools are complete, it is light, etc. Physical and spiritual conditions are also kept because if they are unwell, they will influence and disappear the interest. To raise students' interest to English in English learning, the teacher's role is needed. The efforts that can be done by teacher to raise students' interest to English are:

1. Building the intimate relationship with students, but the teacher does not behave like teenagers. 
2. Explaining the benefits of English learning.

3. Providing the material of lesson which is not difficult, but is not also too easy.

4. Using the tools of lesson which support English learning, and keeping the discipline of class.

5. Showing the enthusiasm in English teaching.

6. Having variation in English teaching, but don't often change the teaching method, because it can make student confused.

7. Appreciating the result of students' effort.

8. Having high spirit and interest to teach English.

9. Having good performance.

From the all of description above, it can be arranged the rationale between vocabulary mastery, English Interest and writing ability. Vocabulary is teh foundation in skill of English. There is vocabulary in listening, writing, speaking, and reading skills. Vocabulary has some kinds of elements and role that is important to be taught. Students must master the vocabulary. Vocabulary mastery can influence writing ability. Writing is the process of gathering and ordering ideas, information, or experiences, then forming them into visible letters or characters in a conventional manner include: correct grammar and structure, vocabulary choice, organization of ideas, spelling, punctuation, cohesion, and coherent. It needs to be planned and organized. Without plan and organization, the ideas will be difficult to render. Another factors that influence writing is interest, Interest is a very important factor because interest has an important role to determine in doing some activities. A student who has interest will study happily and he or she does not feel hard, so he or she can create good writing. Therefore, the researcher assumes that there is a significant correlation between English interest and Writing ability.

\section{RESEARCH METHOD}

The objective of the research is to observe whether or not there is a positive relationship between vocabulary mastery, students' English interest toward writing ability both partially and simultaneously. This research used correlation reasearch method. Correlation research is collection of data to determine whether or to what degree a relationship exists between two or more variables.

This research has two kinds of variables, independent and dependent variable. The independent variables are student's English interest $\left(\mathrm{X}_{1}\right)$ and vocabulary mastery $\left(\mathrm{X}_{2}\right)$, while 
the dependent variable is writing ability (Y), it is design in this figure 1.

Figure 1

the relationship of three variables

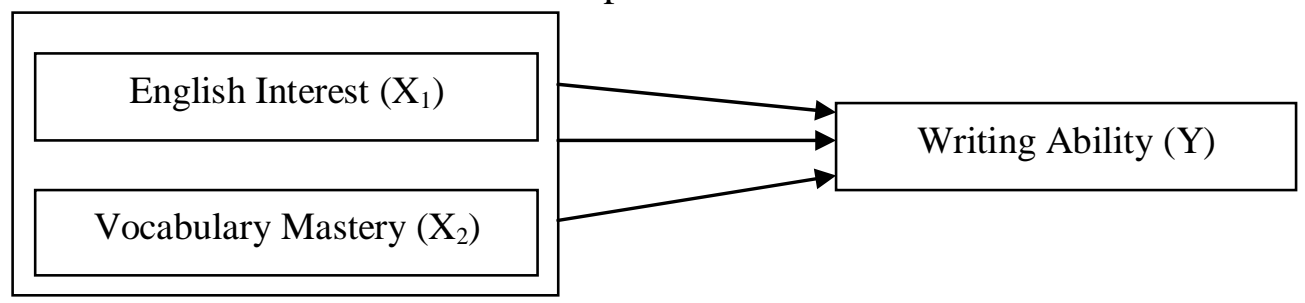

From the figure 1 above, the researcher formulates three hypotheses stating that there is a positive correlation between: (1) vocabulary mastery and writing ability, (2) students“ English Interest and writing ability, and (3) vocabulary mastery and students' English interest simultaneously and writing ability. Afterwards, the researcher also formulates the statistical hypotheses as follows:
1. $\mathrm{H}_{\mathrm{o}}:=0$
$\mathrm{H}_{\mathrm{a}}: \quad>0$
2. $\mathrm{H}_{\mathrm{o}}:=0$
$\mathrm{H}_{\mathrm{a}}: \quad>0$
3. $\mathrm{H}_{\mathrm{o}}: \mathrm{R}_{\mathrm{y} 12}=0$
$\mathrm{H}_{\mathrm{a}}: \mathrm{R}_{\mathrm{y} 12}>0$

This research is carried out for the TOEFL class students of Primary School Teacher and Education Study Program, takes palce in STKIP Muhammadiyah Bangka Belitung. The population in this research is the all of the two TOEFL class students of Primary School Teacher and Education Study Program of STKIP Muhammadiyah Bangka Belitung, taken 30 students as sample by random sampling. To collect the data, the researcher used test in the form of mutiple choice for vocabulary data, and essay test for writing data, and used questionnaire for English interest data. After collecting the data the next step is analyzing them to know whether there is or not a significant correlation between vocabulary mastery and writing ability, students ‘ English interest and writing ability, and between vocabulary mastery, students‘ English interest simultaneously and writing ability.

The researcher tests the hypothesis using Product Moment and Multiple Linear Regression Formula. Product Moment Formula is used to describe the strength of relationship between two variables (single correlation), while Multiple Linear Regression is used to describe the strength between several independents variables and one dependent variable (multiple correlation). Before entering Linear Regression Analysis, there is major pre-requirement analysis for the data. They are normality test using Lilliefors formula, linearity and significance using Anova test. Before taking the data, the instruments are tried 
out to know the validity, reliability, and readability. In this study, the writer used content validity for writing test and English interest questionnaire. They have content validity since the instrument is based on blueprint, blueprint is based on construct, and construct is based on theories. While, for writing instrument, it is tested in the tryout and the coclusion that the writing test order is understandable. The reliability of the vocabulary mastery test is measured by Alpha Cronbach technique, defines the result that vocabulary mastery instrument has high reliability.

\section{RESULT AND DISCUSSION}

There are two measurements in this research, first is descriptive data. The data analyzed are the result of the test and questionnaire. The descriptive statistics among three variables are: 1) for writing score, the mean score is 87.20 ; 2) for English interest, the mean score is 14.73; the last is 3) vocabulary mastery, the mean score of vocabulary mastery is 80.70 . And the second is hypotheses testing.

Before testing the hypotheses, there are pre-requirement tests, they are normality, linearity, and significance data. Normality test is done to find out whether the population is in normal distribution or not. In this research, Kolmogorov-Smirnov test is used to test normality. Based on the result of normality test, it can be concluded that the sample is in normal distribution because the significance value $(0.854)$ is greater than 0.05 . Beside normality test, linearity test is also used by the writer for the pre-requirement analysis. From the computation of linear regression $\mathrm{Y}=66.524+1.403 \mathrm{X}_{1}$, it is obtained that $\mathrm{F}_{\mathrm{o}}=11.646$. This means that $F$ observation is greater than $F$ table $\left(F_{o}=11.646>F_{t}=4.20\right)$; so it can be said that regression is significant. Because $F_{o}$ is lower than $F_{t}\left(F_{o}=0.571<F_{t}=2.55\right)$, the regression is linear. While, computation of linear regression $\mathrm{Y}=65.903+1.063 \mathrm{X}_{2}$, it is obtained that $F_{o}=13.215$. This means that $F$ observation is greater than $F$ table $\left(F_{o}=13.215\right.$ $>4.20$ ); so it can be said that regression is significant. Because F observation is lower than $\mathrm{F}$ table $\left(\mathrm{F}_{\mathrm{o}}=1.063<\mathrm{F}_{\mathrm{t}}=2.41\right)$, the regression is linear.

The first hypothesis said that the correlation between students' English interest and writing ability. From the simple correlation computation of $\mathrm{X}_{1}$ and $\mathrm{Y}$, the coefficient of correlation is $r_{x 1 y}=0.542$. Then, this value is compared to $r$ table at significance level $(\alpha)=$ 0.05 for $\mathrm{N}=30$. It is found that $\mathrm{r}$ table is 0.361 , so $r_{\mathrm{x}}$ is higher than $\mathrm{r}_{\mathrm{t}}$. From the computation, it is also known that the coefficient of correlation between students' English interest $\left(\mathrm{X}_{1}\right)$ and writing ability $(\mathrm{Y})$ is $\mathrm{t}_{\mathrm{o}}=2.952$. For $\mathrm{N}-2=28$ and $\alpha=0.05$, the obtained $\mathrm{t}$-value is greater 
than $\mathrm{t}$-table $\left(\mathrm{t}_{\mathrm{o}}=2.952>\mathrm{t}_{\mathrm{t}}=2.048\right)$. It means that the correlation is significant; so, there is a positive correlation between students' English interest $\left(\mathrm{X}_{1}\right)$ and writing ability $(\mathrm{Y})$.

The second hypothesis stated about the correlation between vocabulary mastery and writing ability. Based on the result of simple correlation computation, the correlation coefficient of $\mathrm{X}_{2}$ and $\mathrm{Y}$ is $\mathrm{r}_{\mathrm{x} 2 \mathrm{y}}=0.566$ and comapred to $\mathrm{r}$ table found 0.361 ; means that $\mathrm{r}$ observation is higher than $\mathrm{r}$ table. From the computation, it is also known that the coefficient of correlation between vocabulary mastery $\left(\mathrm{X}_{2}\right)$ and writing ability $(\mathrm{Y})$ is $\mathrm{t}_{\mathrm{o}}=3.183$. For $\mathrm{N}-2$ $=28$ and $\alpha=0.05$, the obtained $t$-value is greater than $t$-table $\left(t_{0}=3.183>t_{t}=2.048\right)$. It means that the correlation is significant; so, there is a positive correlation between vocabulary mastery $\left(\mathrm{X}_{2}\right)$ and writing ability $(\mathrm{Y})$.

The third hypothesis observe the correlation between students' English interest $\left(\mathrm{X}_{1}\right)$ and vocabulary mastery $\left(\mathrm{X}_{2}\right)$ simultaneously and writing ability $(\mathrm{Y})$. After being calculated by multiple linear regressions, it is found that the coefficient of $\mathrm{a}_{1}, \mathrm{a}_{2}$, and $\mathrm{a}_{0}$ are $1.093 ; 0.212$; and 53.983. Therefore, the multiple regression equation of $Y$ on $X_{1}$ and $X_{2}$ becomes: $\mathrm{Y}=53,983+1.093 \mathrm{X}_{1}+0.212 \mathrm{X}_{2}$

The testing of the significance of the correlation coefficient result for F observation is 12.787. This value is compared to $\mathrm{F}$ table at $5 \%$ significance level and degree of freedom (df) 2 to 27 is 3.35. It is obvious that F observation is greater than F table (12.787 > 3.35). It means that $\mathrm{F}$ observation is significant. So, it can be stated that the regression equation is also significant.

From the multiple correlation analysis of $\mathrm{X}_{1}$ and $\mathrm{X}_{2}$ with $\mathrm{Y}$, the writer finds that the coefficient of correlation $\left(\mathrm{R}_{\mathrm{y} .12}\right)$ is 0.697 . The significance testing of this coefficient in $\mathrm{F}$ observation is 12.787 with $\mathrm{df}=2: 27$ and $\alpha=.05$; admittedly, the $\mathrm{F}$ observation is significant, so that $\mathrm{R}_{\mathrm{y} .12}=0.697$ is also significant.

Thus, the hypothesis stating that there is positive correlation between students English interest, vocabulary mastery, and writing ability is accepted. The conclusion is that there is positive correlation between students' English interest and vocabulary mastery simultaneously and writing ability.

After measuring all of the hypotheses, there are some discussion dealing with the contribution of each variables. A positive correlation means that the increase of students English interest and vocabulary mastery is followed by the increase of writing ability. This kind of correlation creates an assumption that writing ability can be regressed, explained, and 
predicted from students ${ }^{6}$ English interest and vocabulary mastery. Considering that students ${ }^{6}$ English interest and vocabulary mastery have significant role in the writing ability, the teacher should create the process of learning English which can increase the students' vocabulary mastery and maintain the students ${ }^{6}$ interest in English. As a result, it gives contribution for students` English writing ability.

\section{CONCLUSION AND SUGGESTION}

From the result of the measurement, there can be concluded that; first, there is a positive correlation between students ${ }^{6}$ English interest and writing ability of the TOEFL Class students $\left(r_{x 1 y}=0.542>r_{t}=0.361\right)$. It means that the increase of student's English Interest will be followed by the increase of student's writing ability. It also means that the student's English interest has contribution to their writing ability. Second, there is a positive correlation between vocabulary mastery and writing ability of the TOEFL Class students $\left(r_{x 2 y}=0.566>\right.$ $\left.r_{t}=0.361\right)$. It means that the increase of student's vocabulary mastery will be followed by the increase of student's writing ability. It also means that the student's vocabulary mastery has contribution to their writing abilty. Third, there is positive correlation between students ${ }^{6}$ English interest, and vocabulary mastery simultaneously writing ability of the TOEFL class students $\left(\mathrm{R}_{\mathrm{y} .12}=0.697\right.$ and $\left.\mathrm{F}_{0}=12.787>\mathrm{F}_{\mathrm{t}}=3.35\right)$. It means that the increase of student's vocabulary and student's English interest will be followed by the increase of student's writing ability. It also means that the student's English vocabulary mastery and student's English interest have contribution to their writing ability.

Based on the research finding, it has been concluded that there is positive relationship between students' English interest, vocabulary mastery simultaneously and writing ability. It implies that students` English interest and vocabulary mastery are important variables for writing ability. The contribution of both students ${ }^{6}$ English interest and vocabulary mastery for writing ability is $48.6 \%$. It means that $48.6 \%$ variance of writing ability is influenced by students' English interest and vocabulary mastery while the other $51.4 \%$ is contributed by other factors. Therefore, the two variables cannot be neglected in the effort of improving writing ability.

Interest is an important factor for students who want to get good English especially in writing in English. It makes students feel enjoy in learning English. Besides that, the students should have good vocabulary mastery. When students want to create good writing in English, they should improve their vocabulary mastery and interest in English. From those findings 
and conclusion, it is suggested as follows:

How to improve vocabulary so it can increase student's English achievement:

1. Teacher may give colorful pictures about English vocabulary, and the students find the meaning and try to pronouncing.

2. Teacher may use some games related to vocabulary.

3. Teacher may use funny story; like fairy tale, legend, diary, etc. the students try to find the vocabulary in that story and try to find the meaning.

4. Teacher may use English song, video or movie, etc.

To raise students ${ }^{6}$ English interest in English learning, the teacher's role is needed. The efforts that can be done by teacher to raise students' interest to English are:

1. Building the intimate relationship with students, but the teacher does not behave like teenagers.

2. Explaining the benefits of English learning.

3. Having variation and using the tools of lesson which support English learning, and keeping the discipline of class.

4. Appreciating the result of students' effort or giving reward.

5. Having high spirit, good performance and interest to teach English.

Teachers may use some of procedures above to find new vocabularies and they should make the students interested in English lesson. So, the students will pay attention and always try to master their English vocabulary. 


\section{BIBLIOGRAPHY}

Brown, H. Douglas. 2004. Language Assessment: Principles And Classroom Practises. New York: Pearson Education, Inc.

Burhanudin dan Esa Nur Wahyuni. 2009. Teori Belajar dan Pembelajaran. Yogyakarta: ArRuzz Media.

Buscemi, Santi V. 1999. A Reader for Developing Writers. USA: McGraw-Hill Companies, Inc.

Cahyani, I dan Hodijah. 2007. Kemampuan Berbahasa di Sekolah Dasar. Bandung: UPI Press.

Cameron, Lynne. 2001. Teaching Languages to Young Learners. Cambridge: Cambridge University Press.

Coady, J and Huckin. 1998. Second Language Acquisition: a Rationale for Pedagody. New York: Cambridge University Press

Foo, T.,V., et al. 2012. The Effectiveness of Writing Apprehension in English on the Writing Process of Jordanin EFL Students at Yarmouk University. School of Languages, Literacies and Translation University Sains Malaysia

Harris, John. 1993. Introduction Writing. London: Penguin Group.

Hedge, Tricia. 1998. Writing. Oxford: Oxford University Press.

Hughes.1996. Testing for Language Teachers. Cambridge: Cambridge University Press.

Linse, Caroline T. 2006. Practical English Language Teaching: Young Learners. New York: McGraw-Hill Companies.

Nation, I. S. P. 2008. Teaching Vocabulary: Strategy and Teaching. Boston: Heinle Cengage Learning.

Nunan, David. 1998. Language Teaching Methodology. London: Prentice Hall International.

Nunan, David. 1991. Language Teaching Methodology. London: Prentice Hall.

Nurhidayati. 2006. Hubungan antara Minat dengan Prestasi Belajar Siswa dalam Bidang Studi Sejarah Kebudayaan Islam (Thesis). Jakarta: Program Studi Pendidikan Agama Islam Fakultas Ilmu Tarbiyah dan Keguruan UIN Syarif Hidayatullah.

Nur Kholit Hazin. 2004. Kamus Lengkap Bahasa Indonesia. Surabaya: Terbit Terang. Oshima, Alice and Ann Hogue. 2006. Writing Academic English. New York: Pearson Education.

Peha, Steve. 2002. What is Good Writing. www.ttms.org. 
Read, John. 2000. Assessing Vocabulary. Melbourne: Cambridge University Press.

Richards, Jack C. and Theodore S Rodgers. 2001. Approaches and Methods in Language Teaching. Cambridge: Cambridge: Cambridge University Press.

Saleh and Wahab. 2012, July 25. Kabar Pendidikan. Retrieved from http://kabarpendidikan.blogspot.com/2011/03/hakikat-minat-belajar.html

Tarigan, H. G. 2009. Menulis Sebagai Suatu Keterampilan Berbahasa. Bandung: Angkasa

Thornburry, Scott. 2002. How to Teach Vocabulary. UK: Bluestone Press.

Ur, Penny. 1998. A Course in Language Teaching. Cambridge: Cambrigde University Press

Webster, Merriam. 2006. Webster's New Explorer Encyclopedic Dictionary. Springfield: Merriam-Webster Incorporated.

Yule, George. 2006. The Study of Language. Cambridge: Cambridge University Press. 